\title{
Mutation analysis of the BRCA1 gene in 23 families with cases of cancer of the breast, ovary, and multiple other sites
}

\author{
Francine Durocher, Patricia Tonin, Donna Shattuck-Eidens, Mark Skolnick, Steven A \\ Narod, Jacques Simard
}

\begin{abstract}
Germline mutations in the BRCA1 tumour suppressor gene on chromosome 17 q21 are responsible for approximately half of the cases of hereditary breast cancer, including the majority of familial breast/ovarian cancers. To increase our knowledge of the spectrum of BRCA1 mutations, we have extended our analysis to include patients with varied family histories of cancer of the breast, ovary, and at multiple other sites. We have analysed 23 unrelated familial cases using direct sequencing or a combination of dideoxy fingerprinting and sequencing procedures. Twenty one of these families contained three or more cases of breast or ovarian cancer and two families had one case of breast cancer diagnosed before the age of 40 and one case of ovarian cancer. The common frameshift mutation 5382insC was detected in two patients, and the 185delAG mutation was found in a family of Ashkenazi Jewish descent. The novel frameshift mutation 3450del4 (CAAG) was detected in a patient who developed breast cancer at the age of 28 and ovarian cancer at the age of 34 . Three other women in this family were diagnosed with breast cancer at the ages of 26,29 , and 40 . The novel frameshift mutation 2953del3+C was found in a French Canadian woman who had developed two primary cancers of the breast at the age of 37 and 38 and renal cancer at the age of 38 .

(f Med Genet 1996;33:814-819)
\end{abstract}

Key words: BRCA1; breast cancer; ovarian cancer.

It is estimated that $5 \%$ to $10 \%$ of breast and ovarian cancer cases may be attributable to dominantly inherited susceptibility genes. ${ }^{1-6}$ Genetic linkage studies have suggested that germline mutations in the BRCA1 gene located on chromosome $17 \mathrm{q} 21$ are responsible for approximately $75 \%$ of cancers in families with multiple cases of both breast and ovarian cancer. ${ }^{7-14}$ In high risk families, female carriers of BRCA1 mutations have a $80-90 \%$ lifetime risk of breast cancer and a $40-50 \%$ risk of ovarian cancer, and carriers of both sexes have a four-fold increased risk of colon cancer. Male carriers face a three-fold increased risk of prostate cancer. ${ }^{915}$
The BRCA1 gene contains 5592 bp of coding sequence within 22 exons spread over approximately $70 \mathrm{~kb}$, and encodes an acidic protein of 1863 amino acids, ${ }^{16}$ which contains a highly conserved $\mathrm{Cys}_{3}$-His-Cys ${ }_{4}$ RING finger motif near the amino-terminus. Although the precise function of this protein remains to be elucidated, the loss of the wild type allele in breast tumours from linked families supports the hypothesis that BRCA1 acts as a tumour suppressor gene. ${ }^{17-20}$ Moreover, there are data suggesting that BRCA1 is associated with functional differentiation of mammary epithelial cells whereas it may normally serve as a negative regulator of breast cell growth and its expression is under the control of sex steroid hormones. ${ }^{21-25}$ Furthermore, direct evidence has been recently obtained showing that retroviral transfer of the wild type, but not mutant, BRCA1 gene specifically inhibits growth of all breast and ovarian cancer cell lines tested. ${ }^{26}$

Mutation analysis of the BRCA1 gene for women in families with a high incidence of breast/ovarian cancer is now possible. ${ }^{32728}$ During the course of the present study, many distinct germline mutations scattered throughout the coding region were detected with no evidence of clustering, while there is evidence suggesting a correlation between their location and the ratio of breast to ovarian cancer incidence in each family. ${ }^{16-18} 262729-42$ Among the seven distinct mutations that we previously reported in breast/ovarian cancer families ascertained in Canada, four of them, namely 185delAG, 1294del40, 4184del4, and 5382insC, are among the most frequently reported. ${ }^{32} 3943$ Haplotype analysis suggests that these recurrent mutations did not occur de novo but are founder mutations sharing common ancestors. ${ }^{27}{ }^{32}{ }^{44-47} \mathrm{It}$ is also relevant to note that families in which BRCA1 mutations were identified frequently contained cases of cancers at sites other than breast and ovary. Therefore, the present study was undertaken to increase our knowledge of the spectrum of BRCAl mutations in families with cancers of the breast, ovary, and other sites.

\section{Materials and methods}

PATIENT SAMPLES

The 23 breast/ovarian cancer families were referred to the McGill University Hereditary Cancer Clinic at the Montreal General Hospital for genetic counselling, risk assessment, or mutation analysis. All subjects signed appro- \\ Correspondence to: \\ Dr Simard.

Laboratory of
Molecular
Endocrinology, CHUL
Research Center and
Laval University, 2705
Laurier Blvd, Quebec
City G1V 4G2, Canada
F Durocher
J Simard
Departments of
Medicine and Human
Genetics, Division of
Medical Genetics,
McGill University,
Montreal General
Hospital Research
Institute, 1650 Cedar
Ave, Montreal H3G
1A4, Canada
P Tonin
S A Narod
Myriad Genetics, 390
Wakara Way, Salt Lake
City, Utah, USA
D Shattuck-Eidens
M Skolnick
Women's College
Hospital, Toronto M5G
1N8, Canada
S A Narod
Correspondence to:
Dr Simard.
Received 1 March 1996
Revised version accepted for
publication 24 May 1996


priate informed consent forms for participation in the study. Cases of breast/ovarian cancer were verified by review of pathological material, pathology reports, or death certificate information for at least the index case of each family. Families were selected on the basis of (1) three or more cases of breast cancer or ovarian cancer at any age (21 families), or (2) one case of breast cancer diagnosed before the age of 40 and a case of ovarian cancer (two families). In each family one person was studied for BRCA1 mutations by direct sequencing or a combination of dideoxy fingerprinting and sequencing procedures. In general, this was the youngest case of breast cancer available, or a case of ovarian cancer.

MUTATION ANALYSIS BY DIRECT DNA

SEQUENCING

Genomic DNA was extracted from peripheral blood samples from the index case of families $115,277,284,291,337,407,462$, and 474. PCR was performed using 25 sets of primers and the same experimental procedures as previously described. ${ }^{32}$ After 35 cycles, the primers were removed by selective precipitation, and the PCR products were then subjected to a 35 cycle asymmetrical amplification. ${ }^{32}$ Single stranded DNA produced by asymmetrical PCR was sequenced directly by the dideoxy method using the limiting PCR primer or sequence specific primers with the $\mathrm{T} 7$ sequencing kit (Pharmacia LKB Biothechnologies), as previously described. ${ }^{32}$ The BRCA1 coding exons and exon-intron boundaries were sequenced entirely for each of the eight index cases from the above mentioned families, except for exon 4 which was previously found to be non-coding. ${ }^{16}$

Genomic DNA samples from subjects 6 and 11 from family 291 were used to test for the presence of the 185delAG mutation in exon 2, whereas DNA samples from the index cases No 5 from family 289 and No 22 from family 448 were used to determine the presence of 5382insC in exon 20. PCR was performed using exon 2 or exon 20 primer sets under the same experimental procedures as previously described $^{32}$ and the sequence of these BRCA1 exons was determined by direct sequencing of single stranded DNA produced by asymmetrical PCR as previously described. ${ }^{32}$

In order to determine the nature of the novel frameshift mutation 3450 del 4 in index case No 17 from family 407, the region overlapping the mutation was amplified by PCR using the forward primer $5^{\prime}$ CCAAGTACAGTGAGCACAATTA $3^{\prime}$ and the reverse primer 5' AAATGTGCTCCCAAAAGCATAAA 3' and then subcloned in the pCRII plasmid using the TA cloning kit (In Vitrogen). The sequence of the PCR fragment was completed in both orientations.

MUTATION ANALYSIS BY DIDEOXY

FINGERPRINTING AND SEQUENCING

Genomic DNA extracted from peripheral blood samples from the index case of families $103,119,133,146,195,273,283,285,290$, $442,444,461$, and 477 was tested for BRCA1 mutations by dideoxy fingerprinting (DDF) followed by direct sequencing of the region suspected to contain sequence variants using procedures adapted from previously described methods. ${ }^{48}{ }^{49}$ Coding exons and intronic splice donor and splice acceptor regions of the BRCAl gene were screened for mutations. The DDF variants were all verified by direct sequencing. Briefly, PCR was performed using the primer sets previously described ${ }^{32}$ in a $25 \mu 1$ volume containing $10 \mathrm{mmol} / 1$ Tris- $\mathrm{HCl}, \mathrm{pH}$ $8.3,50 \mathrm{mmol} / 1 \mathrm{KCl}, 1.2 \mathrm{mmol} / 1 \mathrm{MgCl}_{2}, 200$ $\mu \mathrm{mol} / 1$ of $\mathrm{dNTPs}, 0.24 \mu \mathrm{mol} / 1$ of each primer, 1.5 U Taq polymerase (Perkin Elmer Cetus), and $4 \mathrm{ng}$ of genomic DNA. The reactions were carried out using a Perkin-Elmer Cetus thermal cycler. After an initial denaturation at $95^{\circ} \mathrm{C}$ for five minutes, the samples were first processed through five cycles consisting of 10 seconds at $95^{\circ} \mathrm{C}, 10$ seconds at $62^{\circ} \mathrm{C}$, and one minute at $72^{\circ} \mathrm{C}$, and thereafter through 35 cycles consisting of 10 seconds at $95^{\circ} \mathrm{C}, 10$ seconds at $58^{\circ} \mathrm{C}$, and one minute at $72^{\circ} \mathrm{C}$. Samples were then incubated with $0.8 \mathrm{U}$ of shrimp alkaline phosphatase and $2.6 \mathrm{U}$ of exonuclease 1 for 30 minutes at $37^{\circ} \mathrm{C}$ followed by 15 minutes at $80^{\circ} \mathrm{C}$ and finally cooled at $4^{\circ} \mathrm{C}$. The DDF reactions were then performed in a $10 \mu \mathrm{l}$ volume using the Cyclist Taq DNA sequencing kit (Stratagene) with approximately $100 \mathrm{ng}$ of PCR product, $0.5 \mathrm{U}$ of Taq DNA polymerase, $2.5 \mu \mathrm{Ci} \alpha[32 \mathrm{P}]-\mathrm{dATP}, 450$ $\mu \mathrm{mol} / 1 \mathrm{ddNTPs}, 10 \mathrm{mmol} / 1$ Tris, $\mathrm{pH} 8.3,50$ $\mathrm{mmol} / \mathrm{l} \mathrm{KCl}$, and $0.025 \mu \mathrm{mol} / 1$ of sequencing primer. After an initial denaturation at $95^{\circ} \mathrm{C}$ for five minutes, the samples were processed through 30 cycles consisting of 15 seconds at $94^{\circ} \mathrm{C}, 15$ seconds at $60^{\circ} \mathrm{C}$, and 30 seconds at $72^{\circ} \mathrm{C}$. The DDF products were then heated for three minutes at $95^{\circ} \mathrm{C}$ and chilled on iced water and $3 \mu \mathrm{l}$ were loaded on a $6 \%$ polyacrylamide gel containing 5\% glycerol. Electrophoresis was performed with $45 \mathrm{mmol} / \mathrm{l}$ Tris-borate, $\mathrm{pH} 8.3$, and $2 \mathrm{mmol} / 1$ EDTA buffer at room temperature at 25 volts for six hours with cooling by a fan. The gel was dried and autoradiographed overnight on one side $x$ ray film.

In order to determine the nature of the novel frameshift mutation 2953del3 $+C$ in index case No 18 from family 290, the region overlapping the mutation was amplified by PCR using the forward primer 5' GTGTGAGTCAGTGTGCAGCA $3^{\prime}$ and the reverse primer $5^{\prime}$ GCCTCTGAACTGAGATGATAGA $3^{\prime}$ and then subcloned in the pCRII plasmid using the TA cloning kit (In Vitrogen). The sequence of the PCR fragment was completed in both orientations. The mutation was also found by direct sequencing of the asymmetrical PCR product thus excluding a cloning artefact.

GENOTYPING OF MICROSATELLITE MARKERS WITHIN OR CLOSE TO THE BRCA1 GENE

The four short tandem repeat markers D17S855, D17S1322, D17S1323, and D17S1327 were genotyped in the index cases from each family using standard procedures. $^{32}{ }^{44}$ Radiolabelled PCR products were electrophoresed on standard $6 \%$ polyacrylamide denaturing sequencing gels. The marker 
Table 1 Characteristics of 23 cancer families tested for BRCA1 mutations

\begin{tabular}{|c|c|c|c|c|c|}
\hline \multicolumn{2}{|c|}{ Family } & $\begin{array}{l}\text { No of cases of } \\
\text { breast cancer }\end{array}$ & $\begin{array}{l}\text { No of cases of } \\
\text { ovarian cancer }\end{array}$ & Other cancers & $B R C A 1$ mutation \\
\hline 103 & & 2 & 1 & & ND \\
\hline 115 & & 3 & 2 & $\mathrm{Bt}$ & ND \\
\hline 119 & & 1 & 3 & & ND \\
\hline 133 & & 11 & 2 & $\begin{array}{l}\text { Bt, Bl, Ki, Lu, } \\
\text { Pro, Psu, Thro }\end{array}$ & ND \\
\hline 146 & & 3 & 0 & Mmel, Pan, Os & ND \\
\hline 195 & & 3 & 0 & $\begin{array}{l}\mathrm{BCC}, \mathrm{Co}, \mathrm{Ki}, \\
\text { Pan }\end{array}$ & ND \\
\hline 273 & & 1 & 1 & & ND \\
\hline 277 & & 6 & 1 & Pro, Ut & ND \\
\hline 283 & & 2 & 1 & Psu & ND \\
\hline 284 & & 3 & 2 & $\begin{array}{l}\text { Co, Mmel, } \\
\text { NHL, Pro, Psu, } \\
\text { Sk, St }\end{array}$ & ND \\
\hline 285 & & 4 & 2 (borderline) & $\mathrm{BCC}, \mathrm{St}$ & ND \\
\hline 289 & & 1 & 1 & & 5382insC \\
\hline 290 & $(\text { No } 15)^{\star}$ & $8 \dagger$ & 1 & $\begin{array}{l}\text { Ki, Li, Pro, } \\
\text { Thro, Psu }\end{array}$ & ND \\
\hline 291 & $\begin{array}{l}\text { (No 18) } \\
\text { (No 5) } \\
\text { (No 6) } \\
\text { (No11) }\end{array}$ & 3 & 1 & Ut & $\begin{array}{l}2953 \text { del3+C } \\
\text { ND } \\
\text { ND } \\
185 \text { delAG }\end{array}$ \\
\hline 337 & & 5 & 1 & Fal & ND \\
\hline 407 & & 4 & 1 & Pan, Sk & 3450del4 \\
\hline 442 & & 1 & $1+1$ (borderline) & $\begin{array}{l}\text { Bl, Bt, Leu, Pan, } \\
\text { St }\end{array}$ & ND \\
\hline 444 & & 0 & 3 & Co & ND \\
\hline 448 & & 2 & 2 & Co, Psu & 5382insC \\
\hline 461 & & 7 & 0 & Bl, Fal & ND \\
\hline 462 & & 7 & 4 & $\begin{array}{l}\text { Co, Cx, Mmel, } \\
\text { Mye, Os, Pro }\end{array}$ & ND \\
\hline 474 & & 2 & 5 & $\begin{array}{l}\text { Co, Eso, Leu, } \\
\text { Psu }\end{array}$ & ND \\
\hline 477 & & 1 & 4 & St & ND \\
\hline
\end{tabular}

ND = no mutation detected.

* Number in brackets corresponds to the No of the subject tested.

† One case of male breast cancer.

BCC: basal cell carcinoma (face); Bl: bladder; Bt: brain tumour; borderline ovarian cancer; Co: colón; Cx: cervix; Eso: oesophagus; Fal: fallopian tube; Ki: kidney; Leu: leukaemia; $\mathrm{Li}$ : liver; Lu: lung; Mmel: malignant melanoma; Mye: myeloma; NHL: non-Hodgkin lymphoma; Os: osteosarcoma; Pan: pancreas; Pro: prostate; Psu: primary site unknown; Sk: skin; St: stomach; Thro: throat; Ut: uterine cancer.
D17S1327 has been located approximately $100 \mathrm{~kb}$ telomeric to the 5 ' region of the BRCA 1 gene, whereas D17S855, D17S1322, and D17S1323 have been located in introns 8, 8, and 2 , respectively. ${ }^{44}$ The estimated allele frequencies of these four markers have been previously reported. ${ }^{32} 4450$

\section{Results and discussion}

The 23 families studied were not tested for linkage because DNA was not available from multiple living affected subjects. Fifteen of these families contained four or more cases of breast or ovarian cancer and six families had three cases (table 1). Two families had only two cases (table 1); the nuclear family 289 was tested because the proband developed breast cancer at the age of 34 and her mother had developed ovarian cancer. In family 273 the proband was diagnosed with ovarian cancer at the age of 37 and her sister developed breast cancer at the age of 37 . Cancers at sites other than breast or ovary are indicated in table 1 .

In our previous mutation analysis of the BRCA1 gene in breast/ovarian cancer families ascertained in Canada, several families were found to share common haplotypes associated with the 185delAG and 5382insC mutations. ${ }^{32}$ Each of these two mutations represents approximately $10 \%$ of patients with BRCA1 mutations. ${ }^{18} 2729303238-414344$ The haplotype of the 23 probands was constructed for the same three short tandem repeat markers within the
BRCA1 gene (D17S855, D17S1322, and D17S1323) and with one marker approximately $100 \mathrm{~kb}$ telomeric to the gene (D17S1327). ${ }^{32}$

The D17S1327 allele $\mathrm{O}$ was detected in the probands of families 289 and 448. The frequency of this rare allele was estimated to be less than $0.01^{44}$ and has been previously detected only in patients bearing the mutation 5382insC. ${ }^{32}{ }^{44}$ As predicted, both proband No 5 in family 289 and patient No 22 in family 448 were carriers of the 5382 ins $C$ mutation, as shown by direct sequencing (fig 1). Unfortunately, it was impossible to test for the presence of the 5382insC mutation in colon cancer cases No 4 and No 5 of family 448 because DNA samples were not available. Moreover, it is of interest to note that the haplotype $\mathrm{D}, \mathrm{E}, \mathrm{F}$, $\mathrm{M} / \mathrm{O}$ of the proband in family 289 is consistent with the haplotype D, E, F, O which is shared in 19 out of 21 subjects studied bearing the 5382insC mutation. ${ }^{32}{ }^{44}$ However, the haplotype $\mathrm{E}, \mathrm{C} / \mathrm{E}, \mathrm{F}, \mathrm{H} / \mathrm{O}$ detected in the index case of family 448 indicates a discrepancy at the D17S855 marker owing to the presence of the $E$ allele, which is two base pairs shorter than the $\mathrm{D}$ allele. The most likely explanation for this observation is a single mutation occurring at D17S855, as previously observed in the index case of family MICH205, who has the haplotype $\mathrm{E}, \mathrm{D} / \mathrm{E}, \mathrm{F}, \mathrm{O} .{ }^{44}$ It has been estimated that the mutation 5382insC has occurred 38 generations ago (90\% limits $18-69) .^{44}$

The 185delAG mutation has been detected in several Ashkenazi Jewish breast and ovarian cancer families from Canada ${ }^{32} 46$ and other countries. ${ }^{18} 30414447$ It has been estimated that this mutation, which has a frequency of about $0.01,{ }^{47}$ occurred 46 generations ago $(90 \%$ limits $23-80) .^{44}$ None of the haplotypes of the index cases tested was consistent with the haplotype of those bearing the mutation $185 \mathrm{del}-$ $\mathrm{AG}^{32} 3844$ and this mutation was not detected by direct sequencing in these 23 people initially selected. However, in proband No 5 of family 291, we analysed the coding region and exon-intron boundaries of the BRCA1 gene by direct sequencing of the PCR products. No mutation was found in this person who had unilateral breast cancer diagnosed in her 50s. Thereafter, we learned that a branch of this family consisting of subjects $1,2,4,5$, and 6 (fig 2) are of Ashkenazi Jewish descent. This information, combined with the haplotype analysis, suggested the possibility that subject No 11 may be a carrier of the 185 delAG mutation. We then sequenced exon 2 of the BRCA1 gene from adult No 11 and found the 185delAG mutation. Furthermore, haplotype analysis of the father of No 11 (No 8) suggested that the mutation has been inherited from his mother (No 9). Our data, combined with the clinical presentation of the family members, suggest that this mutation may account for some cases of breast and ovarian cancer in this family and that the breast cancer case No 5 was a sporadic case. It is also of interest to note that the uterine cancer case No 6 in family 291 is not a carrier of the 185 delAG mutation, as deduced by haplotype analysis 

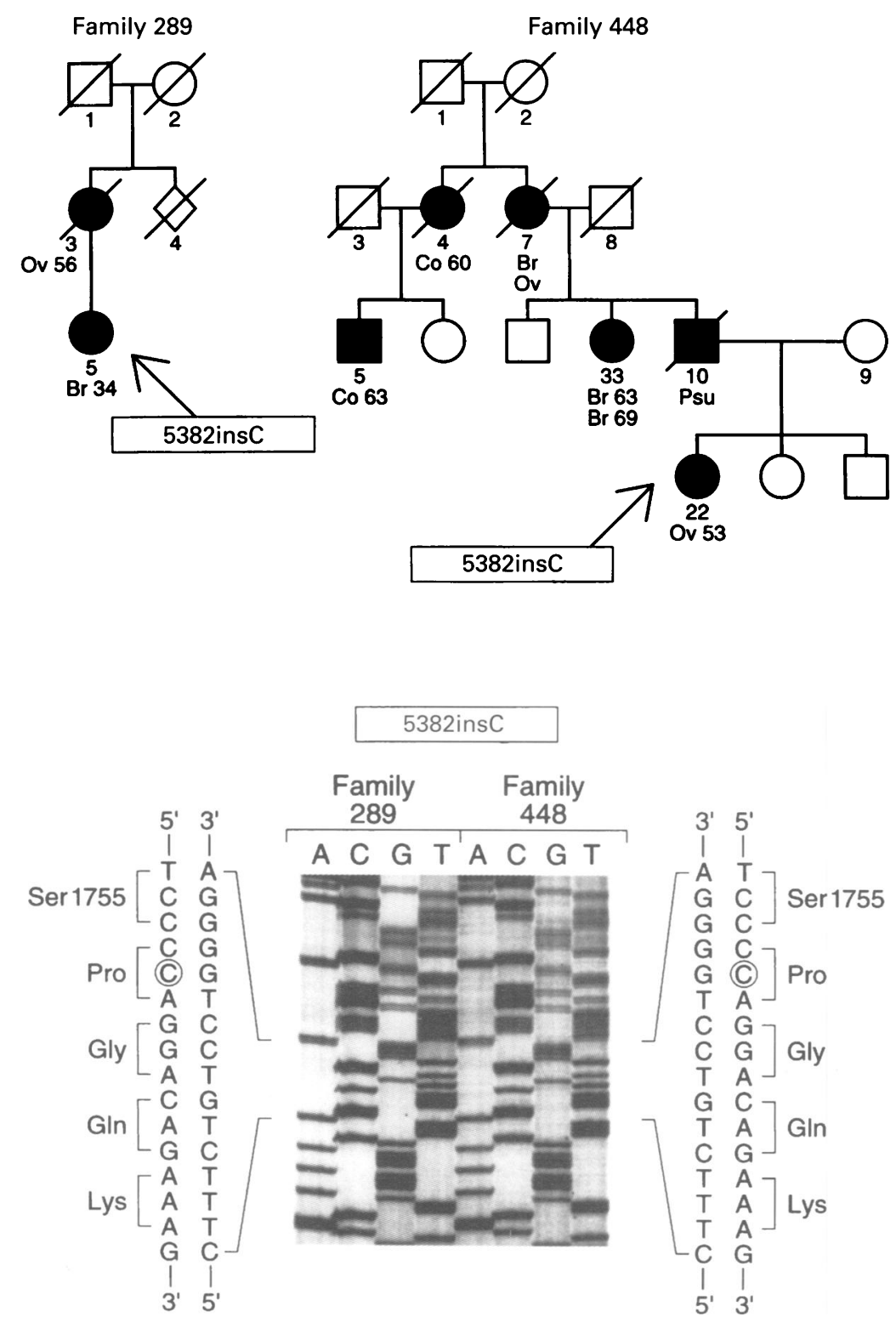

Figure 1 Detection of the frameshift mutation 5382ins $C$ in two families. Panel $A$ : pedigrees of families 289 and 448. Br: breast cancer, Ov: ovarian cancer, Co: colon cancer, Psu:primary site unknown. The numbers following these abbreviations indicate age at diagnosis. The probands carrying the 5382ins $C$ mutation in these families are indicated with an arrow. The subject numbers are shown below the symbols. Panel B: the autoradiograms show only the partial nucleotide sequence obtained by direct sequencing of $P C R$ products and corresponding amino acids of the sense strand of the BRCA1 region including the frameshift mutation 5382insC.

and confirmed by direct sequencing analysis. Also, haplotype analysis of cases No 5 and No 6 suggest that they might carry different BRCA1 alleles (data not shown).

The presence of a novel frameshift mutation in exon 11 designated 3450 del 4 was detected in heterozygote No 17 of family 407 (fig 3). This mutation is the result of the deletion of codon Gln 1111 (CAA) and the first nucleotide (G) of codon 1112 and produces a premature termination codon at position 1115. This women developed breast cancer at the age of 29 and a second primary cancer of the ovary at the age of 34 , whereas her sister developed breast cancer at the age of 29 . The detection of breast cancer in her mother, diagnosed at the age of 40 , and the presence of a maternal relative who developed breast cancer at the age of 26 suggest that this novel frameshift mutation was inherited from her mother.
Dideoxy fingerprinting coupled with direct sequencing analyses showed the presence in exon 11 of the novel frameshift mutation 2953del3+C in heterozygote No 18 in family 290. This screening method is a hybrid between single stranded conformation polymorphism (SSCP) analysis and Sanger dideoxy sequencing involving sequencing reaction with one labelled dideoxynucleotide followed by non-denaturing polyacrylamide gel electrophoresis. ${ }^{45}{ }^{46}$ In addition to being more sensitive than SSCP, this method offers the opportunity to amplify larger fragments (fig 4). The mutation 2953del3+C detected in fig 4 was sequenced and shown to be caused by the deletion of the last two nucleotides of codon 945 and the first nucleotide of codon 946 coupled with the insertion of a $\mathrm{C}$ generating a premature termination codon at 950 (fig 3). This peculiar novel frameshift mutation was identified in the proband who had developed breast cancer at the ages of 37 and 38 and kidney cancer at the age of 38 . This mutation is the first BRCA1 mutation that we found in a French Canadian family. This mutation was not detected in her mother (No 15) and therefore, barring de novo mutation, is deduced to be of paternal origin. This hypothesis is consistent with three breast cancers in this branch of the family. It is unfortunate that we do not have any DNA sample available from additional subjects affected with cancer in this family. The maternal family history is notable for a case of male breast cancer, several female breast cancers, throat cancer, and prostate cancers. All these cancers have been associated with BRCA2. It remains possible that the proband is a carrier of a mutation in both genes; it is therefore premature to attribute the renal cancer to the BRCA1 mutation.

In the 18 families in which mutations were not detected, only five were clear examples of

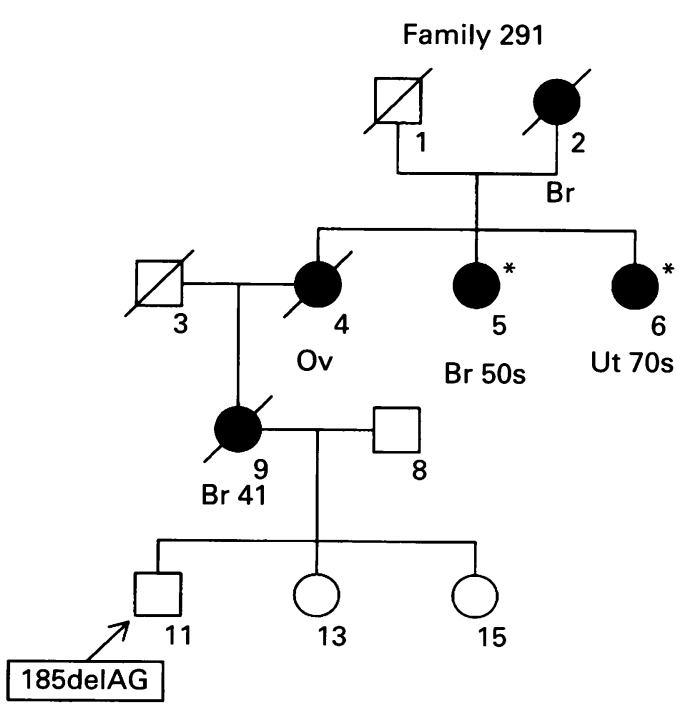

Figure 2 Pedigree of family 291. Br: breast cancer, Ov: ovarian cancer, Ut: uterine cancer. The numbers following these abbreviations indicate age at diagnosis. The subject numbers are shown below the symbols. Adult No 11 in this pedigree bearing the 185 delAG mutation is indicated with an arrow, whereas this mutation was not found in the initial index case No 5 or her sister No 6 who are indicated with an asterisk. 

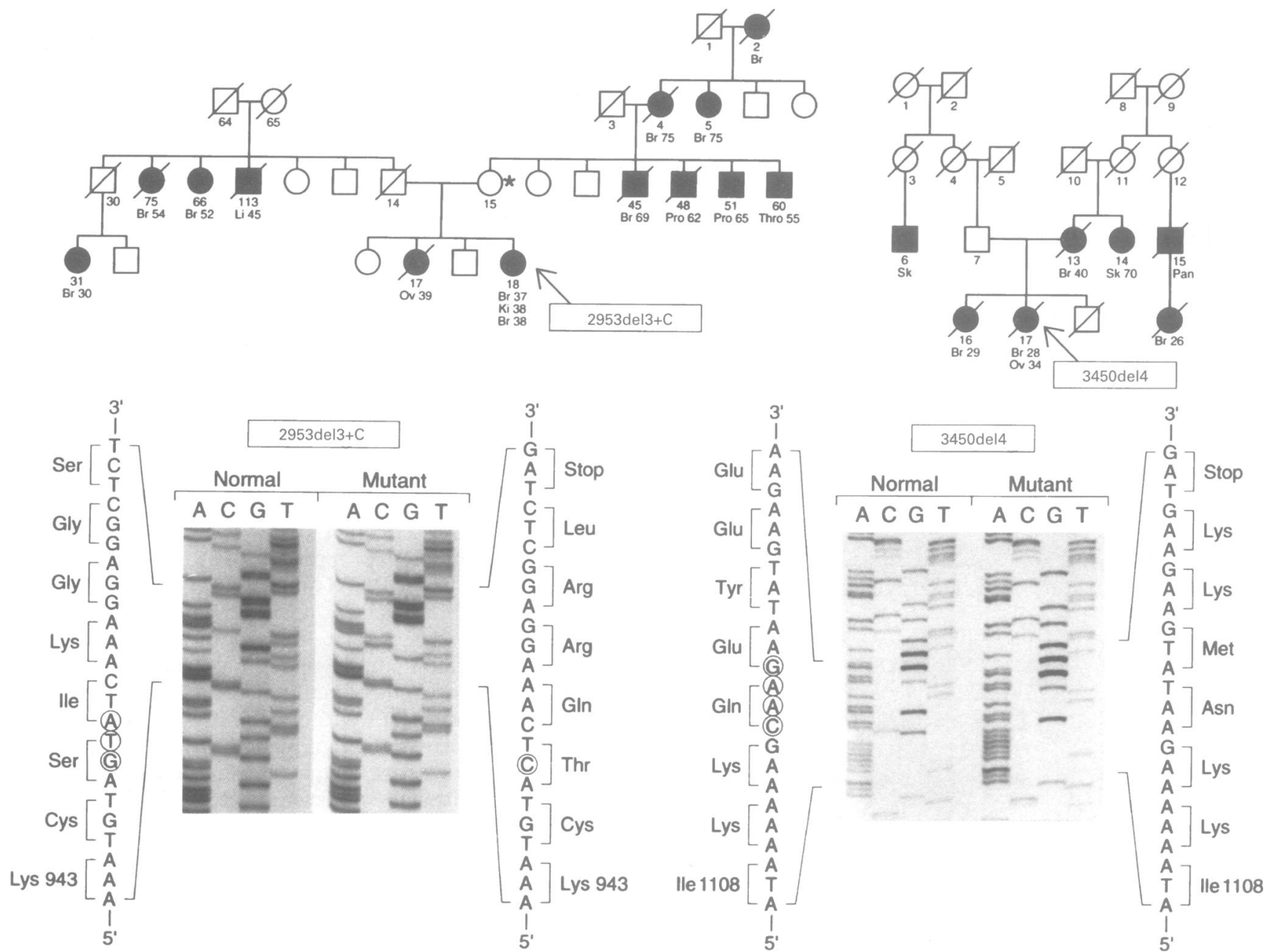

Figure 3 Detection of two novel frameshift mutations in two Canadian families. Upper panel: pedigrees of families 290 and 407 . Br: breast cancer, Ov: ovarian cancer, Pro: prostate cancer, Ki: kidney cancer, Li: liver cancer. Sk: skin cancer, Pan: pancreatic cancer. The numbers following these abbreviation indicate age at diagnosis. The subject numbers are shown below the symbols. Note that proband No 18 in family 290 bearing the mutation 2953 del $3+C$ who developed two primary cancers in the same breast and kidney cancer is indicated with an arrow, whereas this mutation was not found in her mother No 15 (asterisk). Note that proband No 17 in family 407 bearing the mutation $3450 d e l 4$ is indicated with an arrow. Lower panel: the autoradiograms show only the partial nucleotide sequence and corresponding amino acids of the sense strand of the BRCA1 regions including the frameshift 2953 del $3+C$ and 3450 del 4 mutations after subcloning of PCR products into the $p C R I I$ plasmid. The mutation 2953 del $3+C$ produces a premature termination codon at position 950, whereas the mutation 3450 del 4 generates a termination codon at 1115 . The sequence of the normal alleles for the corresponding regions are indicated on the left. The nucleotide encircled in normal sequences are deleted in the mutant BRCA1 alleles, while for the mutant allele 2953 del $3+C$ the $C$ encircled is added. The BRCA1 mutations were designated according to the suggested nomenclature. ${ }^{\text {sI }}$

the breast/ovarian syndrome (two or more cases each of breast and ovarian cancer). It is expected that the majority of families of this type are the result of BRCA1. ${ }^{13}$ We cannot rule out the possibility that some mutations were located within regions not screened in the BRCA1 gene leading, for example, to aberrantly spliced mRNA species, a lower level of BRCA1 gene expression, or transcript instability, which may account for $15-20 \%$ of disease associated mutations. ${ }^{52}$ However, four of the above mentioned families were unusual in that there was a remarkable number of cancers of other sites in these families, including the brain, bladder, kidney, lung, prostate, throat, pancreas, and colon. It may be that the appearance of cancer of multiple other sites is characteristic of cancer susceptibility genes other than BRCA1. Studies to verify the involvement of BRCA2, a second breast cancer susceptibility gene mapped to $13 \mathrm{q} 12-13,{ }^{53-55}$ are under way in these families. In addition, the high frequency of sporadic breast and ovarian cancer suggests the possibility that we may have studied a sporadic case, as was found with family 291 .

The two families with borderline ovarian cancers (285 and 442) were negative for the BRCA1 mutation. This is in keeping with our earlier observation that borderline tumours are not part of the hereditary ovarian cancer spectrum. ${ }^{6}$ Also, we studied two families ( 337 and 461 ) with breast cancer and cancer of the fallopian tube, following our observation of a BRCA1 mutation segregating in a family with cancer of the fallopian tube. ${ }^{32}$ Surprisingly, both families were negative for BRCA1 mutations.

BRCA1 mutations were thus found in only five of 23 families tested. However, in contrast to our previous study of families ascertained in Canada, ${ }^{32}$ there were no linkage data supporting the presence of a BRCA1 mutation in these families. Where possible, we currently look for evidence of linkage to the BRCA1 locus at $17 \mathrm{q} 21$ or the BRCA2 locus at $13 \mathrm{q} 12$-q13 before proceeding to sequencing analysis, 


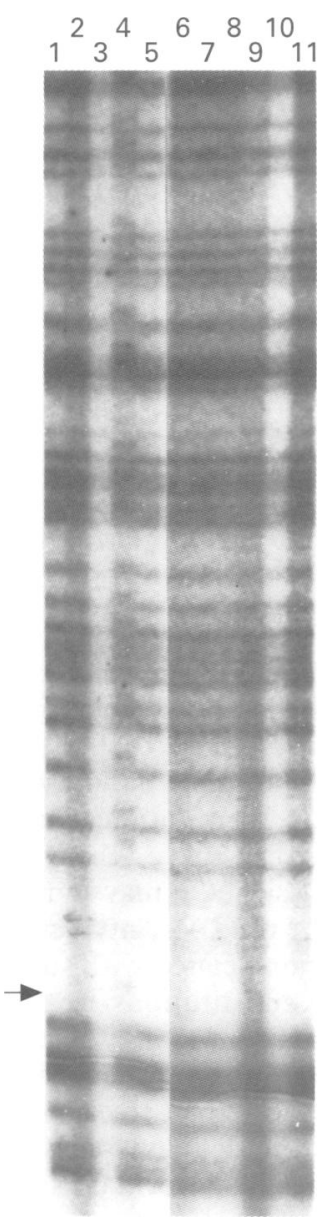

Figure 4 Autoradiograph of a dideoxy fingerprinting gel of the sense strand of the $B R C A 1$ region including the 2953del $3+C$ mutation Eleven DNA samples were screened as described in Materials and methods. The starting point of the alteration in the band pattern in the sample from proband No 18 of family 290 (lane 4) correlates with the localisation of the heterozygous 2953 del $3+C$ mutation in this patient. which is time consuming and technically challenging. However, although there is no evidence that there is clustering of BRCA1 mutations, it may be appropriate to use initial and rapid alternative screening procedures as recently developed. ${ }^{43}$

We thank Martine Tranchant, Carolle Samson, and Carole Bélanger for their expert assistance and Dr David Rosenblatt and Maria Galvez for the detection of the mutation 185delAG in family 291 . We also thank physicians who contributed to this study including $\mathrm{R}$ Margolese, D Cole, D Gilchrist, B McGillivray, B Rosen, J Buchanan, I Warner, M Pollock, and R Carter, as well as the family members for their much appreciated collaboration. This work was supported by a Medical Research Council (MRC) of Canada grant to JS, Endorecherche, Myriad Genetics Inc, Canadian Genetic Disease Network (Federal NCE Program) and the Fonds de la Recherche en Santé du Québec (FRSQ), and the US Army grant DAMD 17-94-J-4299. FD is recipient of a Studentship from the MRC, JS is a MRC scholar, SN is supported by the Canadian Breast Cancer foundation Ontario Chapter, and PT is a MRS/CRS Scholar.

1 Foulkes WD, Narod SA. Hereditary breast and ovarian cancer: epidemiology, genetics, screening and predictive testing. Clin Invest Med 1995;18:473-83.

2 Claus EB, Risch N, Thompson WD. Genetic analysis of breast cancer in the cancer and steroid hormone study. $\mathrm{Am}$ 7 Hum Genet 1991;48:232-41.

3 Hoskins KF, Stopfer JE, Calzone KA, et al. Assessment and counseling for women with a family history of breast counseling for women with a family history of breas

4 Peto J, Easton DF, Mattews FE, et al. Cancer mortality in relatives of women with breast cancer: the OPCS study. Int 7 Cancer 1996;65:275-83.

5 Easton DF, Matthews FE, Ford D, et al. Cancer mortality in relatives of women with ovarian cancer: the OPCS study. Int $\mathcal{F}$ Cancer 1996;65:284-94.

6 Narod SA, Madlensky L, Bradley L, et al. Hereditary and familial ovarian cancer in Southern Ontario. Cancer 1994; 74:2341-6

7 Hall JM, Lee MK, Newman B, et al. Linkage of early-onset familial breast cancer to chromosome 17q21. Science 1990;250:1684-9.

8 Narod S, Feunteun J, Lynch HT, et al. Familial breastovarian cancer locus on chromosome 17q12-q23. Lancet 1991;338:82-3.

9 Easton DF, Bishop DT, Ford D, et al. Genetic linkage analysis in familial breast and ovarian cancer: results from 214 families. Am f Hum Genet 1993;52:678-701.

10 Simard J, Feunteun J, Lenoir G, et al. Genetic mapping of the breast-ovarian cancer syndrome to a small interval on chromosome $17 \mathrm{q} 12-\mathrm{q} 21$ and exclusion of candidate genes 17ß-HSD II and RARA. Hum Mol Genet 1993;2:1193-9.

11 Easton DF, Ford D, Bishop DT, and the Breast Cancer Linkage Consortium. Breast and ovarian-cancer incidence in BRCA1-mutation carriers. Am $\mathcal{f}$ Hum Genet 1995; 56:265-71.

12 Ford D, Easton DF, Peto J. Estimates of the gene frequency of BRCA1 and its contribution to breast and ovarian cancer incidence. Am f Hum Genet 1995;57:1457-62.

13 Narod SA, Ford D, Devilee P, et al. A heterogeneity analysis of 145 breast-ovarian cancer families. Am $\mathcal{f}$ Hum Genet of 145 breast-ovar

14 Tonin P, Moslehi R, Green R, et al. Linkage analysis of 26 Canadian breast and breast-ovarian cancer families. Hum Genet 1995;5:535-41.

15 Ford D, Easton DF, Bishop DT, et al. Risks of cancer in BRCA1-mutation carriers. Lancet 1994;343:692-5.

16 Miki Y, Swensen J, Shattuck-Eidens D, et al. A strong candidate for the breast and ovarian susceptibility gene BRCA1. Science 1994;266:66-71.

17 Castilla LH, Couch F, Erdos M, et al. Mutations in the BRCA1 gene in families with early onset breast and ovarian cancer. Nature Genet 1994;8:387-91

18 Takahashi $\mathrm{H}$, Behbakht $\mathrm{K}$, McGovern PE, et al. Mutation analysis of the BRCA1 gene in ovarian cancers. Cancer Res 1995;55:2998-3002.

19 Smith SA, Easton DF, Evans DGR, et al. Genetic heterogeneity and localization of a familial breast-ovarian cancer gene on chromosome 17q12-21. Nature Genet 1992;

20 Neuhausen SL, Marshall CJ. Loss of heterozygosity in familial tumors from three BRCA1-linked kindreds. Cancer Res 1994;54:6069-72.

21 Lane TF, Deng C, Elson A, et al. Expression of BRCA1 is associated with terminal differentiation of ectodermally and mesodermally derived tissues in mice. Gene Dev 1995; 9:2712-22.

22 Thompson ME, Jensen RA, Obermiller PS, et al. Decreased expression of BRCA1 accelerates growth and is often present during sporadic breast cancer progression. Nature Genet 1995;9:444-50.

23 Marquis ST, Rajan JV, Wynshaw-Boris A, et al. The developmental pattern of BRCA1 expression implies a role in differentiation of the breast and other tissues. Nature Genet 1995;11:17-26.

24 Gudas JM, Nguyen H, Li T, et al. Hormone-dependent regulation of BRCA1 in human breast cancer cells. Cancer Res 1995;55:4561-5.
25 Spillman MA, Bowcock A. Estrogen stimulation of the breast BT- 483 breast cancer cell line results in increased levels of BRCA1 and ETV4 mRNAs. Am 7 Hum Genet Suppl 1995;57:A5 (abst 14).

26 Holt JT, Thompson ME, Szabo C, et al. Growth retardation and tumor inhibition by BRCA1. Nature Genet 1996; 12:298-302.

27 Shattuck-Eidens D, McClure M, Simard J, et al. A collaborative survey of 80 mutations in the BRCAl breast and ovarian cancer susceptibility gene: implications for presymptomatic testing and screening. $\mathcal{F} A M A$ 1995;273:53541 .

28 American Society of Human Genetics. Statements of the American Society of Human Genetics on genetics testing for breast and ovarian cancer predisposition. Am $\mathcal{f} \mathrm{Hum}$ Genet 1994:55:i-iv.

29 Friedman LS, Ostermeyer EA, Szabo CI, et al. Confirmation of BRCA1 by analysis of germline mutations linked to breast and ovarian cancer in ten families. Nature Genet 1994;8:399-404

30 Struewing JP, Brody LC, Erdos MR, et al. Detection of eight BRCA1 mutations in 10 breast/ovarian cancer families, including 1 family with male breast cancer. Am $7 \mathrm{Hum}$ Genet 1995;57:1-7.

31 Futreal PA, Liu Q, Shattuck-Eidens D, et al. BRCA1 mutations in primary breast and ovarian carcinomas. Science 1994;266:120-2.

32 Simard J, Tonin P, Durocher F, et al. Common origins of BRCA1 mutations in Canadian breast and ovarian cancer families. Nature Genet 1994;8:392-8.

33 Hogervorst FBL, Cornelis RS, Bout M, et al. Rapid detection of BRCA1 mutations by the protein truncation test. Nature Genet 1995;10:208-12

34 Inoue R, Fukutomi T, Ushijima T, et al. Germline mutation of BRCA1 in Japanese breast cancer families. Cancer Re 1995;55:3521-4.

35 Plummer SJ, Anton-Culver H, Webster L, et al. Detection of BRCA1 mutations by the protein truncation test. Hum Mol Genet 1995;4:1989-91.

36 Durocher F, Shattuck-Eidens D, McClure $\mathrm{M}$, et al. Comparison of BRCA1 polymorphisms, rare sequence variants and/or missense mutations in unaffected and breast/ovarian cancer populations. Hum Mol Genet 1996; 5:835-42.

37 Boyd M, Harris F, McFarlane R, et al. A human BRCA1 gene knockout. Nature 1995;375:541-2.

38 Gayther SA, Warren W, Mazoyer S, et al. Germline mutations of the BRCAl gene in breast and ovarian cancer families provide evidence for a genotype-phenotype correlation. Nature Genet 1995;11:428-33.

39 Couch FJ, Weber BL. Breast Cancer Information Core. Mutations and polymorphisms in the familial early-onset breast cancer (BRCA1) gene. Hum Mutat (in press)

40 Serova $\mathrm{O}$, Montagna $\mathrm{M}$, Torchard $\mathrm{D}$, et al. A high incidence of BRCA1 mutations in 20 breast-ovarian cancer families. Am $\mathcal{F}$ Hum Genet 1996;58:42-51.

41 Friedman LS, Szabo CI, Ostermeyer EA, et al. Novel inherited mutations and variable expressivity of BRCA1 alleles, including the founder mutation 185delAG in Ashkenaz Jewish families. Am f Hum Genet 1995;57:1284-97.

42 Phelan CM, Rebbeck TR, Weber B, et al. Ovarian cancer risk in BRCA1 carriers is modified by the HRAS 1 variable number of tandem repeat (VNTR) locus. Nature Gene 1996;12:309-11

43 Gayther SA, Harrington P, Russell P, et al. Rapid detection of regionally clustered germ-line BRCA1 mutations by multiplex heteroduplex analysis. Am f Hum Genet 1996;58:451-6.

44 Neuhausen SL, Mazoyer S, Friedman L, et al. Haplotype and phenotype analysis of six recurrent BRCA1 mutations in 61 families: results of an international study. Am $\mathcal{F ~ H u m}$ Genet 1996:58:271-80.

45 Durocher F, Bélanger C, Labrie F, et al. Detection, haplotype and phenotype analysis of two common BRCA mutations. Proc 2nd foint Clinical Genetic Meeting, Los Angeles, 1995:108(abst 64)

46 Tonin P, Serova O, Lenoir G, et al. BRCA1 mutations in Ashkenazi Jewish women. Am f Hum Genet 1995;57:189.

47 Struewing JP, Abeliovich D, Perezt T, et al. The frequency of the BRCA1 185delAG mutation is approximately $1 \%$ in Ashkenazi Jewish individuals. Nature Genet 1995;11:198200.

48 Sarkar G, Yoon HS, Sommer SS. Dideoxy fingerprinting (ddF): a rapid and efficient screen for the presence of mutations. Genomics 1992;13:441-3.

49 Blaszyk H, Hartmann JJ, Schroder RM, et al. Rapid and efficient screening for p53 gene mutations by dideoxy fingerprinting. Biotechniques 1995;18:256-60

50 Neuhausen SL, Swensen J, Miki Y, et al. A P1-based physical map of the BRCA1 region from Di7S776 to D17S78. Hum Mol Genet 1994;3:1919-26.

51 Beaudet AL, Tsui LC. A suggested nomenclature for designating mutations. Hum Mutat 1993;2:245-8.

52 Szabo CI, King MC. Inherited breast and ovarian cancer. Hum Mol Genet 1995;4:1811-17.

53 Wooster R, Neuhausen SL, Mangion J, et al. Localization of a breast cancer susceptibility gene, BRCA2, to chromosome 13q12-13. Science 1994;265:2088-90.

54 Wooster R, Bignell G, Lancaster J, et al. Identification of the breast cancer susceptibility gene BRCA2. Nature 1995; 378:789-92.

55 Tavtigian SV, Simard J, Rommens J, et al. The complete BRCA2 gene and mutations in chromosome 13q-linked
kindreds. Nature Genet 1996;12:333-7. 